\title{
Sąžiningos prekybos plėtros galimybės Lietuvoje
}

\begin{abstract}
Straipsnyje nagrinèjama Są̌iningos prekybos (angl. Fairtrade), kaip socialinės atsakomybès reiškinio ir ekonominès veiklos fenomeno, koncepcija, raida, šio tipo produktų gamybos, realizavimo ir sertifikavimo ypatumai. Ypatingas dėmesys skiriamas Sąžiningos prekybos produktų atpažistamumui ir jų realizavimo augimo Lietuvoje trikdžiams identifikuoti bei šios socialiai atsakingos veiklos platesnio taikymo galimybių paieškai. Remiantis mokslinès literatūros sistemine analize ir šio straipsnio autorių atlikta vartotojų bei prekybos organizacijų vadovų ir vadybininkų apklausa, pristatomas Sąžiningos prekybos produktų realizavimo plètros mūsų šalyje modelis ir jo iggyvendinimo algoritmas.
\end{abstract}

Raktiniai žodžiai: Sąžininga prekyba, socialinė atsakomybė, ženklinimas, sertifikavimas, standartas, darnusis vystymasis.

The article examines Fairtrade, as a phenomenon of social responsibility and commercial activities, its concept, evolution, aspects of the Fairtrade products' manufacture, marketing, and certification. Particular attention is paid to the spread of information about Fairtrade products, identification of obsticals for the turnover growth in Lithuania and the search for wider application of this socially responsible tool. Based on the systematic analysis of scientific literature and the conducted survey of consumers, trade CEOs and managers, the authors propose a model of Fairtrade products' development in Lithuania.

Keywords: Fairtrade, social responsibility, marking, certification, standard, sustainable development.

\section{Ivadas}

Sąžiningos prekybos (SP), kaip su darniuoju vystymųsi susietos socialinès atsakomybès reiškinio ir naujos tarptautinès ekonominès veiklos fenomeno, užuomazgos atsirado daugiau kaip prieš 60 metų. SP siekia skaidrių ir dorų komercinių santykių su trečiųjų šalių gamintojais, suteikdama jiems galimybes gauti teisingą atlygi už savo darbą, sudarydama saugesnes darbo sąlygas, teikdama premijas minètų šalių bendruomenių vystymui. İsigydami per Sąžiningos prekybos sistemą teikiamas prekes turtingesnių šalių vartotojai gauna kokybišką ir saugų maistą bei kitus produktus, kurių gamybos ir prekybos sąlygas griežtai reglamentuoja šios srities tarptautiniai standartai ir reguliuoja atsakingos

Alina KAIRAITYTĖ - Vilniaus universiteto Ekonomikos fakulteto Kokybès vadybos magistrè. Tel.: +370 698 79349. El. p.: alina.kairaityte@gmail.com.

Juozas RUŽEVIČIUS - habilituotas mokslų draktaras, Vilniaus universiteto Ekonomikos fakulteto Vadybos katedros profesorius. Adresas: Saulètekio al. 9, II rūmai, 715 kab., LT-10222 Vilnius, Lietuva. Tel.: +379 68609710. El.p.: juozas.ruzevicius@ef.vu.lt. 
organizacijos. Sąžiningos prekybos ideja realias apraiškas igijo tik XX a. viduryje (Comfort,et al., 2003; Blowfield, Dolan, 2010), o jos produktų kokybę reglamentuojančių standartų, sertifikavimo ir ženklinimo sistema yra vis dar kuriama ir vystoma. Sąžiningos prekybos sertifikavimo ženklu pažymètas prekes jau keletą dešimtmečių galima ịsigyti užsienio šalių prekybos centruose, socialinę atsakomybę propaguojančiose parduotuvèlèse (angl. Worldshops, Fair Trade Shops). Kaip skelbia apklausos - daugiau nei pusè išsivysčiusių ES šalių vartotojų gerai suvokia, kas tai yra SP ir jos produktai, perka šias prekes ir sutinka už jas mokèti iki 1030\% brangiau (Nicholls, 2002; Fairtrade..., 2011; Ruževičius, 2012b).

Užsienio šalių autoriai savo moksliniuose darbuose plačiai analizuoja Sąžiningos prekybos koncepciją, sampratą ir sąvokas (Loureiroa, 2005; Eisenberg, 2005; Smith, 2011), SP kaip socialinès atsakomybès judejimo raidą bei SP koncepcijos formavimosi etapus (Jones, et al., 2003; Hockerts, 2005; Blowfield, Dolan, 2010) bei sertifikavimo ir ženklinimo ypatumus (Kocken, 2006; Jaffee, 2010; Gibbon, et al., 2012). Tuo tarpu Lietuvoje šiam klausimui skiriamas tik fragmentiškas dèmesys - ne tik nèra sisteminių mokslinių tyrimų ir straipsnių šia tema, bet ir žiniasklaidos priemonèse informacija apie Sąžiningos prekybos prasmę, ši judejimą ir jo tikslus nèra pakankamai viešinama (Ruževičius, 2011; 2012a; 2012b). Ir nors Lietuvoje tokių prekių issigyti jau galima, tačiau vartotojų vertybinių orientacijų, socialinio atsakingumo stoka bei SP produktų ženklo menkas atpažǐstamumas neskatina šių produktų pardavimų.

Problema. Straipsnio autoriai kelia klausimą, koks Sąžiningos prekybos plètros modelis yra tinkamas diegti Lietuvoje, siekiant paskatinti SP sistemos igyvendinimą ir užtikrinti šių produktų realizavimo tvarų augimą. SP problematikos taikomąji aktualumą patvirtina ir tai, kad ES šiuo metu inicijuoja keletą kompleksinių tyrimų, nukreiptų i Sąžiningos prekybos idejos sklaidą ir populiarinimą ES šalyse, jos koncepcijos konsolidavimą, vartotoju ir prekybos organizacijų darbuotojų socialinio atsakingumo ugdymą, informuotumo didinimą ir šių produktų realizavimo Europoje plètrą.

Straipsnio tikslas - išanalizavus Sąžiningos prekybos koncepciją ir sistemą, parengti SP produktų realizavimo plètros galimybių Lietuvoje modelį. Tikslui pasiekti buvo keliami tokie pagrindiniai uždaviniai:

1) išanalizuoti Sąžiningos prekybos sąvokas, raidos aspektus ir sertifikavimo ypatumus;

2) sugretinti SP produktų pardavimo apimtis ir paplitimą Lietuvoje ir pasaulyje;

3) ištirti esamą Sąžiningos prekybos produktų žinomumą ir esamą paklausą Lietuvoje;

4) atlikus užsienio autorių tyrimų analizę, nustatyti Sąžiningos prekybos produktų pardavimus ribojančius veiksnius ir numatyti SP plètros skatinimo Lietuvoje galimybes;

5) suformuoti Sąžiningos prekybos produktų realizavimo pletros galimybių Lietuvoje modeli.

Tyrimo metodai. Straipsnyje buvo taikyti mokslinès literatūros ir dokumentų sisteminès analizès, lyginimo, apklausos, struktūrizuoto interviu bei sintezès metodai. Tyrimo duomenų statistinè analizè atlikta naudojant SPSS ir Microsoft Office Excel (2010) programinius paketus. Kintamųjų statistiniams skirtumams ivertinti buvo pasitelkti nepriklausomų 
imčių testai, chi-kvadrato $\left(\chi^{2}\right)$ kriterijus. Statistinis skirtumo tarp rodiklių reikšmingumas buvo vertinamas pagal reikšmingumo lygmens koeficientą (p): kai $\mathrm{p}<0,05$, rodiklių skirtumai buvo laikyti statistiškai reikšmingais. Patikimumo vertinimui buvo naudojamas Cronbach alfa kriterijus. Neparametriniams duomenims ivertinti taip pat buvo taikomas McNemar testas, parametriniams - pakartotinių vertinimų dispersinè analizè.

Tyrimo metu buvo nustatyta, kad beveik pusė apklaustų Lietuvos vartotojų nèra net girdèję apie Sąžiningą prekybą. Supažindinus respondentus su SP ideja ir esme bei jos produktų ypatumais paaiškèjo, kad paklausa šioms prekèms egzistuoja. Daugiau kaip pusė apklaustų Lietuvos vartotojų sutiktų už SP produktus mokèti daugiau, kadangi šie produktai visumoje yra sveikesni, neturi genetiškai modifikuotų organizmų ir priedų. Respondentams taip pat rūpi ir socialinis aspektas - pagalba trečiųjų šalių ūkininkams ir darbininkams. Interviu su prekybos centrų atstovais, atsakingais už prekių asortimento formavimą, rezultatai atskleidè, kad prekybininkai kol kas nèra pakankamai suinteresuoti prekiauti šia produkcija, nes SP produktai, apklaustujų nuomone, tik „išaldo“ lèšas ir yra palyginti mažo apyvartumo, kadangi Lietuvos vartotojai nesuvokia SP esminių siekių ir nežino šių produktų ypatumų. Kita vertus, prekybos organizacijų respondentai pažymèjo, kad jie būtų suinteresuoti platinti SP gaminius tuo atveju, jei galètú juos parduoti brangiau. Taigi, reikalingas tiek Lietuvos vartotojų, tiek ir prekybos organizacijų vadovų ir darbuotojų švietimas bei ugdymas socialinès atsakomybės (SA) ir vartojimo ekologinès kultūros srityse. Remdamiesi atlikto tyrimo rezultatais autoriai parengè SP produktų realizavimo plètros modelį, kurio igyvendinimas leistų veiksmingiau plètoti Lietuvoje Sąžiningą prekybą ir didinti šių prekių pardavimą.

\section{Sąžiningos prekybos koncepcija, sistema ir raida}

Sąžiningos prekybos idèją išvystè Vakarų šalių pilietinès visuomenès decentralizuotos interesų grupès. Dèl šios priežasties yra daug skirtingų SP apibrèžimų (Loureiroa, 2005). „Traidcraft", didžiausios Didžiojoje Britanijoje SP organizacijos, vadovų manymu Sąžininga prekyba siekia pakeisti ir pagerinti neturtingų gamintojų ekonominị ir socialinị gyvenimą besivystančiose šalyse, igalinant juos naudotis savo igūdžiais ir ištekliais, kad sukurtų nuolatinius pragyvenimo šaltinius sau ir savo bendruomenėms. Pasaulinè SP organizacija (angl. World Fair Trade Organization) teigia, kad Sąžininga prekyba yra atsakas i tradicinès prekybos nesugebejjimą užtikrinti vargingiausioms pasaulio šalims pastovaus pragyvenimo ir vystymosi galimybių. Europos Komisija pabrèžia, kad Sąžiningos prekybos tikslas - užtikrinti, kad gamintojai ir darbuotojai gautų tokias pajamas, kurios atspindi tikrąsias idetas pastangas, išteklius, siekiant sukurti tokias sąlygas, kurios užtikrintų didesnę socialinę ir aplinkos apsaugą besivystančiose šalyse. Pagal „Fair Trade Foundation", Sąžininga prekyba yra alternatyvus požiūris į tradicinę prekybą, kuris yra pagrịstas gamintojų ir vartotojų partneryste. SP laiduoja gamintojams geresnius sandorius ir prekybos sąlygas, o tai, savo ruoštu, suteikia jiems galimybę pagerinti savo gyvenimą ir ateities perspektyvas. Šiuo metu plačiausiai naudojamas Tarptautinès sąžiningos prekybos asociacijos (angl. Fairtrade International) SP apibrèžimas, kuris 
teigia, jog „Sąžininga prekyba yra prekybos partnerystè, pagrista dialogu, skaidrumu ir pagarba, kuria siekiama didesnio teisingumo tarptautineje prekyboje. Ji prisideda prie nuolatinio ir darnaus vystymosi, suteikdama geresnes prekybos salygas ir apsaugodama gamintoju ir darbuotoju teises, ypač Pietinèse pasaulio šalyse“.

SP raida apibendrinta 1 pav. Pirmieji mąstymai apie tarptautinio verslo teisingumą ir sąžiningumą aptinkami olandų kilmès rašytojo Eduard Douwes Dekker 1859 m. išleistoje knygoje „Max Havelaar“, kurioje pabrèžiama nesąžininga kavos prekyba tarp Nyderlandų ir Indonezijos. Knygoje pagrindinis veikejjas Max Havelaar palieka Nyderlandu prekybos kompaniją tam, kad galètų dirbti solidariai kartu su vietiniais Indonezijos gyventojais (Redfern, et al., 2002). Kiti užsienio autoriai (Jones, et al., 2003; Blowfield, Dolan, 2010) SP judejimo pradžią sieja su alternatyvios prekybos organizacijomis (angl. Alternative trade organizations - ATO`s), kurias steige bažnyčios ir labdaros organizacijos, o jos ilgainiui tapo nepriklausomomis organizacijomis, kurios pirko produktus ir rankdarbius iš nepasiturinčių gamintojų. Dauguma parduodamų produktų dar nebuvo specialiai paženklinti, tačiau organizacijos identiškumas garantavo, kad produktai buvo issigyti laikantis Sąžiningos prekybos principų (Comfort, et al., 2003).

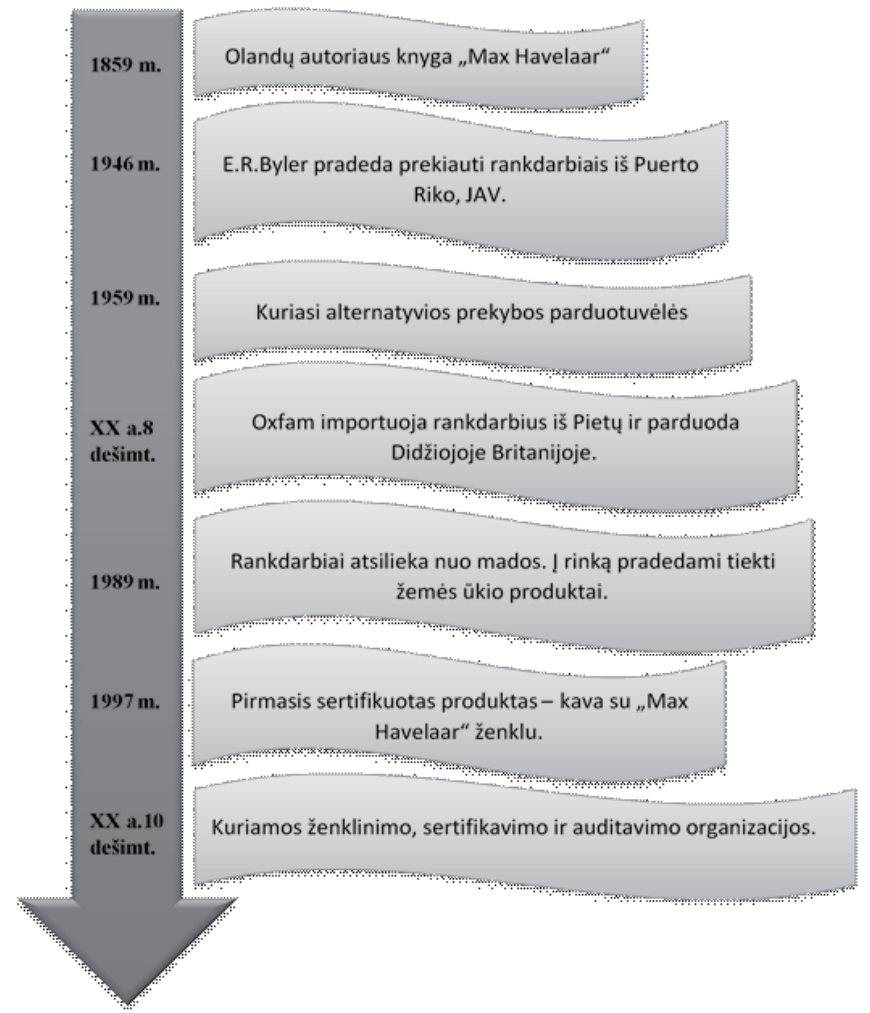

1 pav. Sąžiningos prekybos raidos etapai.

Šaltinis: sudaryta autorių. 
Pirmieji realios SP pradai atsirado JAV. 1946 m. Edna Ruth Byler vyko savanoriauti i Puerto Riką, kuriame ji sutiko daug skurstančių moterų, kurios pragyvenimui užsidirbo iš lininių rankdarbių. Po šešerių metų ji su savo kolega iš savanorių "Mennonite“ bendruomenès Ruth Lederach nusivežè porą rankdarbių ì Šveicarijoje vykusią pasaulio konferenciją ir sèkmingai juos pardavè. Tai laikoma pirmaja prekyba, kuri vyko sąžiningai.

Pirmosios Sąžiningos prekybos apraiškos buvo labiau tradicinè pagalba skurstančių šalių gamintojams. Tai buvo prekès iš trečiųjų šalių, dažniausiai įvairūs rankdarbiai, kurie neturejo didesnès materialinès ar estetinès vertès. Todèl iš tikrųų ši veikla buvo ta pati parama, tiesiog pridengta prekyba (A. Tallontire Cit. pagal: Hockerts, 2005). Verslo motyvas dažniausiai yra pelno siekimas. Taigi atsirado įžvalgų ir iniciatyvų, kad alternatyva tik pelno siekiančiam verslui gali būti Sąžininga prekyba, paremta jos produktų ir gamybos griežta sertifikavimo sistema, standartais ir socialinès atsakomybès principais (Redfern, et al., 2002). Po keletą dešimtmečių vykusio SP judejjimo augimo ir plètojimosi, buvo sukurta pasaulinè Sąžiningos prekybos sertifikavimo ir ženklinimo sistema, kuri garantavo vartotojams, kad jų pirkiniai tikrai duoda naudą trečiųjų šalių gamintojams.

Sertifikuojantys organai yra nepriklausomos trečiosios šalys, kurios yra laikomos patikimomis vertinti SP verslo veiklą. Yra skiriami du Sąžiningos prekybos organizacijų tipai, kurie įeina ị ši procesą:

- produktų sertifikuotojai, kurie audituoja produktų gamintojus, sertifikuoja juos kaip Sąžiningos prekybos gamintojus ir stebi visą tiekimo grandinę, nuo tos vietos, kur produktas yra gaminamas iki pat jo pardavimo vietos;
- organizaciju vertintojai, kurie nesertifikuoja produktų, bet audituoja ir vertina didmenininkus ir mažmenininkus, parduodančius SP produktus ir leidžia minètiems verslininkams tapti vertinimo organizacijos nariais, jeigu jų immonès praktikuoja Sąžiningą prekybą (Jones, et al., 2012). Pagrindinè pasaulyje produktus sertifikuojanti organizacija yra FLO-Cert. Ši istaiga kilo iš „Fairtrade Labelling Organizations International" organizacijos, kuri $2004 \mathrm{~m}$. sausị buvo padalinta ị dvi nepriklausomas organizacijas („Fairtrade International“ ir „FLO-Cert"), siekiant užtikrinti Sąžiningos prekybos sertifikavimo ir ženklinimo sistemos skaidrumą ir nepriklausomumą.

1997 m. įkūrus FLO, buvo parengti ir harmonizuoti pasauliniai standartai, kurių paskirtis - palaikyti ūkininkų ir plantacijų darbininkų veiklos plètrą labiausiai nuskurdusiose pasaulio šalyse.

Pagrindiniai standartų tikslai, kuriuos ìvardija Tarptautinè sąžiningos prekybos organizacija yra šie:

- užtikrinti, kad gamintojai gautu kainas, kurios padengia vidutinius produkcijos kaštus;

- suteikti papildomas Sąžiningos prekybos premijas, kurios gali būti investuotos ị socialinę ir ekonominę plètrą bei aplinkosaugą stiprinančius projektus;

- suteikti išankstinius apmokèjimus gamintojams, kuriems to reikia;

- palengvinti ilgalaikès prekybos partnerystę ir geriau kontroliuoti gamintoją visame prekybos procese;

- nustatyti aiškius pagrindinius vystymosi kriterijus tam, kad visų SP sertifikuotų produktų gamybos ir prekybos sąlygos būtų socialiai ir ekonomiškai teisingos bei nekenktų aplinkai.

2002 m. FLO organizacija sukūrè tarptautini Sąžiningos prekybos sertifikavimo ženklą (žr. 2 pav., pirmas iš kairès), kuriuo 


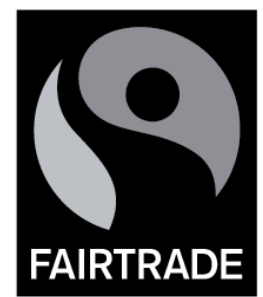

(B)
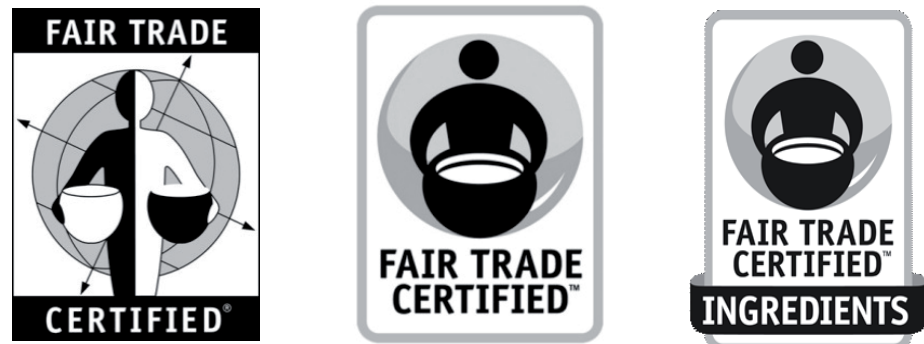

2 pav. Sąžiningos prekybos produktų sertifikavimo ženklai.

yra žymimi visi produktai, sertifikuoti pagal FLO leidžiamus standartus. Šio ženklo tikslas - pagerinti SP gaminių matomumą prekybos centrų lentynose,

palengvinti užsienio kompanijų prekybą ir supaprastinti eksporto procedūras tiek gamintojams, tiek eksportuotojams (Fairtrade Foundation, 2012).

\section{Sąžiningos prekybos produktų pardavimai bei juos ribojantys veiksniai}

Sąžininga prekyba pasaulyje kasmet sulaukia vis didesnio vartotojų demesio. Šis judejimas plinta sparčiais tempais, ir tai atspindi tarptautinių SP organizacijų pateikiama statistika. „Fairtrade International“ 2012-2013 m. metiniame pranešime nurodo, kad:

- sąžiningos prekybos tinklui jau priklauso daugiau kaip 1,3 mln. ūkininkų ir darbuotojų 66 pasaulio šalyse;

- $50 \%$ gamintojų turi balso teisę priimant sprendimus;

- sąžininga prekyba jungia 1149 gamintojų organizacijas;

- 20-yje pasaulio šalių 1300 miestų yra paskelbti Sąžiningos prekybos miestais;

- 2012 m. išmokèta $80 \mathrm{mln}$. eurų premijų nepasiturintiems gamintojams;
- 6 iš 10 apklaustųjų yra matę SP sertifikavimo ženklą, ir 9 iš 10 mačiusiųjų juo pilnai pasitiki (Fairtrade..., 2013).

Sąžiningos prekybos pasaulinè lyderè yra Didžioji Britanija, po jos seka JAV, Vokietija ir Prancūzija (žr. 1 lentelę). 2011 m., palyginus su 2010 m., SP produktų pardavimai išaugo 12\%. Didžiausias augimas pastebimas Pietų Afrikos Respublikoje (283\%), taip pat Ispanijoje (39\%), Japonijoje (29\%), Olandijoje (24\%). Deja, Lietuvoje pokytis buvo neigiamas (-17\%), kaip ir Estijoje, kur 2011 m., lyginant su 2010 m., SP produktų buvo nupirkta $18 \%$ mažiau. Autorių nuomone, Lietuvoje pokytis buvo neigiamas dèl dviejų priežasčių. Visų pirma, mūsų šalies piliečiai dar menkai suvokia SP esmę ir jos ženklais pažymètų produktų ypatumus. Antra, Lietuvos vartotojai vis dar taupo dèl neseniai praejusios finansų krizès ir nežino bei nesupranta, kaip pirkdami Sąžiningos prekybos ženklu pažymėtas prekes gali daryti teigiamą poveiki trečiojo pasaulio žmonèms.

Sąžininga prekyba Lietuvoje vis dar žengia pirmuosius savo žingsnius. Tik $2008 \mathrm{~m}$. per radiją ir spaudą buvo pristatyta pirmoji informacine medžiaga apie SP. Taip pat Lietuvoje nèra atskiros organizacijos, kuri rūpintųsi SP produktų ženklinimu, platinimu ir viešinimu. Šiuo 
metu už Sąžiningos prekybos ženklo naudojimo Lietuvoje licencijas atsakinga Suomijos SP paramos asociacija.

Kokiu būdu būtų galima didinti vartotojų susidomejjimą ir šių produktų pardavimo apimtis? Suzanne Mathieu ir Alain d'Astous 2008 metais atliktame tyrime nustatė, jog konkrečią informaciją žmonès ìsimena daug geriau, negu abstrakčias detales, todèl geriau yra teikti konkrečius faktus apie SP naudą trečiosioms šalims. Taip pat veikia socialinio pripažinimo kriterijus - jei aplinkiniai pirko prekę, kyla poreikis ir pačiam tai išbandyti. Ir galiausiai, grižtamojo ryšio aspektas - pravartu būtų vartotojams gauti atsaką iš trečiųjų šalių ùkininkų, kuriems Sąžininga prekyba padeda išgyventi ir plèsti savo bendruomenes.

C. Strong (1997) bei A. J. Nicholls (2002) ịvardijo pagrindinę problemą, kuri neleidžia SP produktų vartotojų elgsenoje igyvendinti Sąžiningos prekybos principų. Autorių nuomone, vartotojai nesupranta, kad žmogiškasis elementas taip pat įeina ị ekologijos struktūrą. Mūsų visų poelgiai atsispindi aplinkoje ir turi jai poveikį. Taigi didžiausias iššūkis, kuris šiuo metu laukia Sąžiningos prekybos iniciatorių, yra didesnès vartotojų paklausos sužadinimas bei dèmesio patraukimas SP produktais, o taip pat Sąžiningos prekybos visuotinis pripažinimas (Nicholls, Opal, 2005).

Sandy Wynne (2008) savo darbe išskyrè pagrindinius iššūkius Sąžiningos prekybos produktų rinkodaroje: painiava (terminologijoje, ženklinime, sertifikavimo sistemoje); sąmoningumo, tinkamumo ir prieinamumo problemos (trūksta knygų SP tematika, sunku rasti produktus pagrindinèse apsipirkimo vietose); kontraversiškumas (užsienio prekyba kartais dar labiau nuskurdina atsilikusias šalis; dalis pardavejjų SP ženklais naudojasi kaip marketingo priemone).
Taigi ìsivardinti pagrindines problemas, trukdančias SP produktų pardavimams tiek pasaulyje, tiek Lietuvoje yra svarbiausia, o problemų sprendimo būdai ir išplaukia iš juc pačiuc - nusistatyti vieningą Sąžiningos prekybos terminologiją, bendrą ženklinimo sistemą, palengvinti produktų pateikimą ì didžiuosius prekybos centrus, skleisti Sąžiningos prekybos idejas ir viešinti šios prekybos pasiektus rezultatus ir poveiki trečiųjų šalių gyventojams ir produkcijos gamintojams.

\section{Sąžiningos prekybos situacijos Lietuvoje tyrimas}

Sąžininga prekyba yra palyginti retai sutinkamas terminas lietuviškoje spaudoje, žiniasklaidoje ar mokslinèse publikacijose. Ir nors palyginus su kitomis užsienio valstybėmis, Lietuvoje SP judejimo atgarsiai tik labai nežymūs, tačiau jos apraiškų pamažu galime sutikti tiek didžiuosiuose prekybos centruose („Rimi“, „Maxima“, "Iki“), tiek smulkiajame versle („One Planet Shop \& Lounge") ir kt.

Pagrindinis šios tyrimo dalies tikslas - nustatyti, ar yra paklausa Sąžiningos prekybos produktams Lietuvoje ir ar būtų galima užtikrinti tinkamą šių produktų pasiūlą prekybos centruose. Tam ištirti buvo atlikta internetine vartotojų apklausa ir žvalgomasis tyrimas - didžiųjų Lietuvos prekybos centrų („Rimi“, „Maxima“, Iki“, „Norfa“) vadovų ir vadybininkų interviu.

SP produktų paklausos nustatymo Lietuvoje tyrime dalyvavo 20-60 metu amžiaus Lietuvos vartotojai. Pagal Lietuvos statistikos departamento pateikiamus duomenis, Lietuvoje $2012 \mathrm{~m}$. pradžioje gyveno 1646626 šios amžiaus grupès 
Sąžiningos prekybos produktų pardavimų pokytis 2010-2011 m. pagal šalis

\begin{tabular}{|c|c|c|c|}
\hline Valstybè & 2010 m. (eur.) & $2011 \mathrm{~m}$. (eur.) & Pokytis \% \\
\hline Australija/NZ & 125.940 .187 & 150.276 .220 & $19 \%$ \\
\hline Austrija & 87.000 .000 & 100.000 .000 & $15 \%$ \\
\hline Belgija & 72.000 .000 & 77.000 .000 & $7 \%$ \\
\hline Kanada & 194.935 .883 & 199.768 .996 & $3 \%$ \\
\hline Čekija & 2.704 .370 & 2.859 .432 & $6 \%$ \\
\hline Danija & 62.535 .857 & 74.908 .637 & $20 \%$ \\
\hline Estija & 606.247 & 496.640 & $-18 \%$ \\
\hline Suomija & 93.001 .210 & 102.673 .112 & $10 \%$ \\
\hline Prancūzija & 303.314 .314 & 315.416 .709 & $4 \%$ \\
\hline Vokietija & 340.000 .000 & 400.544 .747 & $18 \%$ \\
\hline Airija & 138.000 .000 & 158.864 .349 & $15 \%$ \\
\hline Italija & 49.400 .006 & 57.542 .552 & $16 \%$ \\
\hline Japonija & 14.434 .289 & 19.386.202 & $29 \%$ \\
\hline Latvija & 425.936 & 492.031 & $16 \%$ \\
\hline Lietuva & 751.776 & 624.091 & $-17 \%$ \\
\hline Liuksemburgas & 6.200 .000 & 7.491 .910 & $21 \%$ \\
\hline Olandija & 119.000 .000 & 147.300 .000 & $24 \%$ \\
\hline Norvegija & 43.756 .694 & 53.617 .544 & $23 \%$ \\
\hline Pietų Afrika & 1.898 .889 & 7.273 .254 & $283 \%$ \\
\hline Pietų Korèja & - & 17.106 .828 & $\mathrm{n} / \mathrm{a}$ \\
\hline Ispanija & 14.363 .009 & 20.026 .046 & $39 \%$ \\
\hline Švedija & 108.477 .630 & 134.335 .702 & $17 \%$ \\
\hline Šveicarija & 219.918 .679 & 264.754 .487 & $20 \%$ \\
\hline D. Britanija & 1.343 .956 .837 & 1.498.207.592 & $12 \%$ \\
\hline JAV & 936.973 .359 & 1.030 .670 .695 & $10 \%$ \\
\hline Likusi pasaulio dalis & 39.443 .874 & 74.741 .866 & $89 \%$ \\
\hline Iš viso: & 4.319.039.047 & 4.916.379.643 & $12 \%$ \\
\hline
\end{tabular}

Šaltinis: Fairtrade International (2011).

asmenų. Imties skaičiavimui pasirinkta tikimybinè atranka, kai elementai (šiuo atveju - ì 20-60 metų grupę papuolantys vartotojai) atrenkami atsitiktiniu būdu ir kiekvieno elemento tikimybè patekti i imti yra vienoda. Skaičiuojant reikiamą imtị ir norint užtikrinti imties pakankamą reprezentatyvumą populiacijos atžvilgiu, nuspręsta nustatyti $95 \%$ pasikliovimo lygmenị su 5\% imties paklaidos tikimybe. Atliekant tyrimą, ị tikslinę grupę pakliuvo 142 vyrai ir 264 moterys, ir tai pilnai tenkino imties kriterijų: esant 95\% pasikliovimo lygmeniui su 5\% imties paklaidos tikimybe, reikejo apklausti 384 Lietuvos vartotojus. Surinktų duomenų analizè buvo atliekama SPSS programos ir Microsoft Excel programiniu paketu. 
Internetinès apklausos rezultatai parodè, jog apie 50\% respondentų Sąžiningos prekybos terminą girdi pirmą kartą, 29\% yra kažkur girdejję ir 21\% tiksliai žinojo, kas yra SP (žr. 3 pav.). Tai rodo, jog Lietuvoje šio judejjimo atgarsiai vis dar menki, ir reikètų rūpintis informacijos apie Sąžiningą prekybą sklaida bei vartotojų socialinio atsakingumo ugdymu.

Supažindinus respondentus su SP ideja ir esme bei jos produktų ypatumais paaiškejjo, kad paklausa šioms prekèms gali egzistuoti ir Lietuvoje. Dauguma SP produktų kartu yra ir ekologiški, todèl paklausa SP prekėms yra siejama ir su paklausa ekologiškiems produktams. $\mathrm{Nu}$ statyta, kad net 97\% asmenų, vartojančių ekologiškus produktus, taip pat pirktų ir SP produktus, o iš nevartojančiųjų ekologiškų produktų - 17\% visuomet rinktųsi Sąžiningos prekybos produktus vietoj iprastinių produktų, o 73\% - retkarčiais juos taip pat įsigytų (žr. 4 pav.).

Didesnè dalis vartotojų pirktų šiuos produktus net ir esant aukštesnei kainai
- taip teigia 54\% respondentu. Atlikus chi-kvadrato testą pastebèti skirtumai tarp demografinių rodiklių: moterų didesnè dalis (58\%) sutiktų mokèti daugiau negu vyru (45\%), Pearson Chi-Square lygus $6,533, p<0.05$. Taip pat asmenys, kurių amžius 40-50 metų už Sąžiningos prekybos gaminius būtų linkę mokèti daugiau (74\%) negu jaunesnio amžiaus respondentai turintys 30-40 metus (45\%). Tyrimo metu nustatyta, jog svarbiausiu kriterijumi, renkantis maisto produktus, vartotojai laiko gaminio sudètį. Atlikus McNemar testą, buvo nustatyta, jog vartotojai pirktų Sąžiningos prekybos produktus ne dèl to, kad juos parduoda ir jie pažymèti garsaus gamintojo etikete, bet vartotojai tiki Sąžiningos prekybos nauda ne tik jiems patiems, bet ir trečiosioms šalims, ir tam įrodyti nereikia garsaus prekès ženklo (chi-kvadrato reikšmė lygi 9,633, p<0.05).

Atlikus pakartotinių vertinimų dispersinę analizę, buvo nustatyta, kad svarbiausias veiksnys, didinant SP produktų

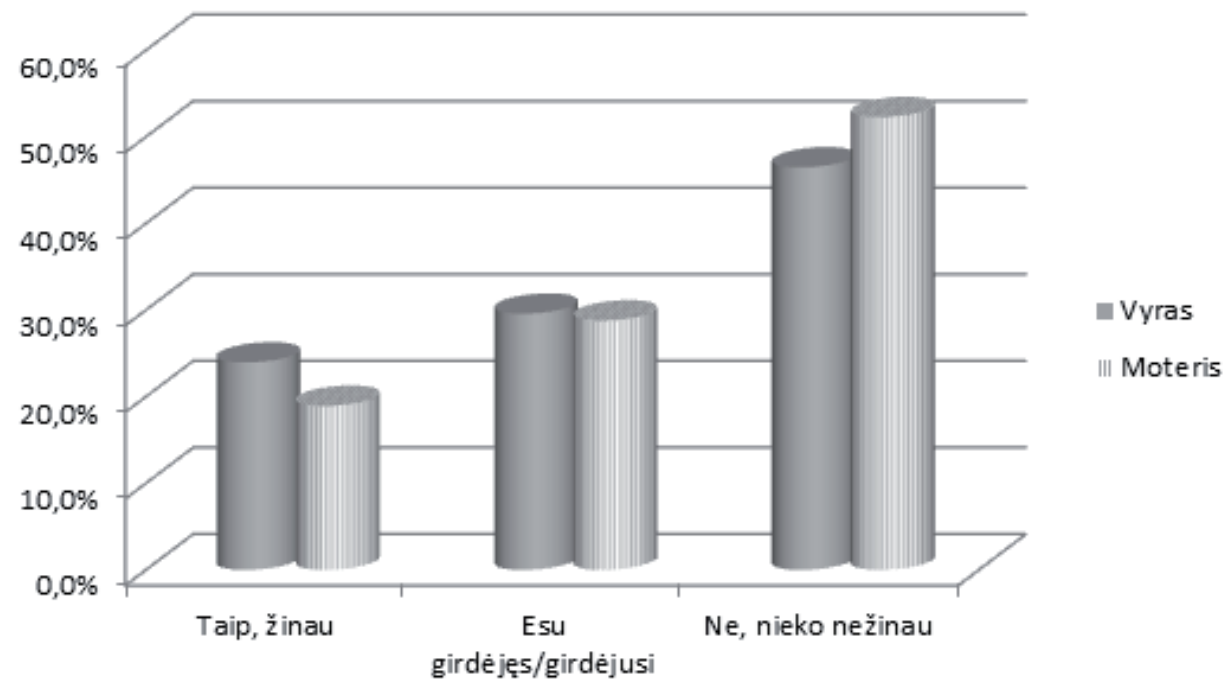

3 pav. Vyrų ir moterų pasiskirstymas pagal žinias apie Sąžiningą prekybą. 


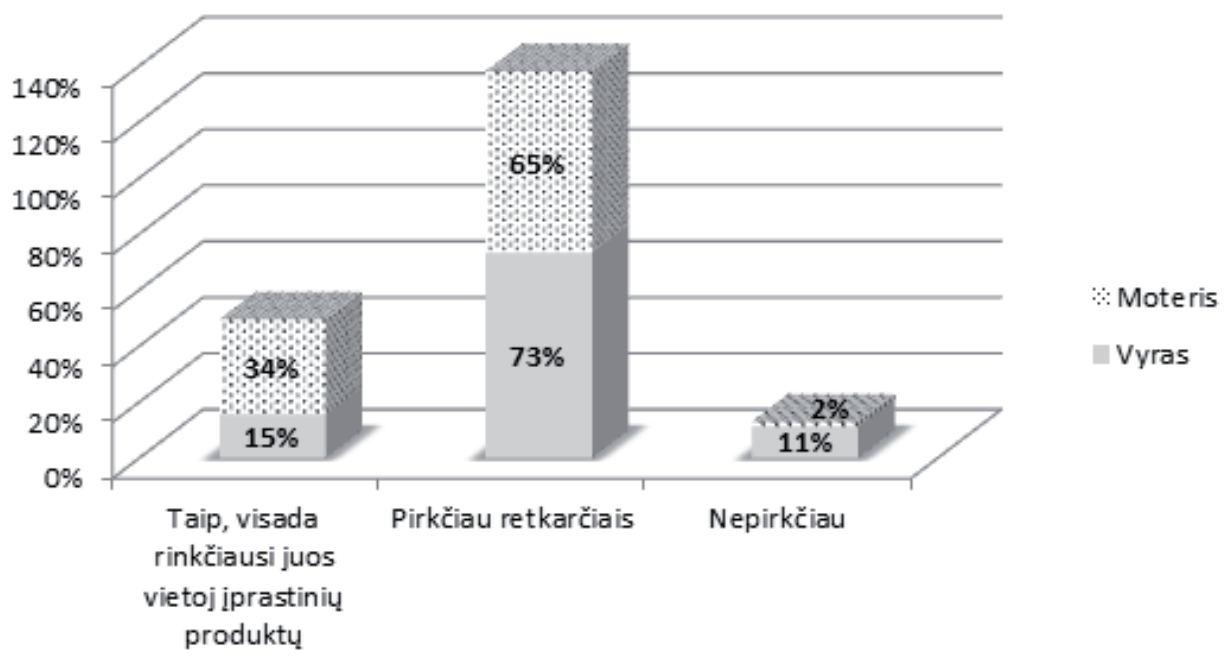

4 pav. „Sąžiningos prekybos“ produktų potenciali paklausa (pagal vartotojo lytį).

pardavimus ir vartojimą, yra platesnè informacijos sklaida apie šio judejjimo esmę ir tikslus, produktų ypatumus ir jų pardavimo vietas (ịvert. 4,29 iš 5 ; $\mathrm{p}<0.05$ ). Taip pat nustatyta, jog vartotojams yra svarbesnis šių produktų pasirinkimo didinimas prekybos centruose negu specializuotų skyrelių ar atskirų parduotuvių tinklų steigimas (ịvert. 3,3 iš 5; p $<0.05$; vertinamų teiginių Cronbach alfa kriterijus: $0,75>0,6)$.

Siekiant išsiaiškinti prekybos atstovų požiūrị ị Sąžiningos prekybos plètros galimybes Lietuvoje, buvo atliktas žvalgomasis tyrimas. Struktūrizuoto klausimyno interviu buvo apklausti Lietuvos didžiųjų prekybos centrų („Maxima“, „Iki“, „Rimi“ ir „Norfa“) atstovai, atsakingi už prekių asortimento formavimą jų tinklo parduotuvėse. Jų buvo prašoma pasidalinti savo patirtimi ir įžvalgomis bei atsakyti i iš anksto paruoštus dešimt klausimų, kurių pagalba galima ịvertinti, kokiu būdu prekybos centrų darbuotojai atsirenka produktus, kuriais bus prekiaujama, kokie kriterijai yra svarbiausi ir kokios galimybès plèsti Sąžiningos prekybos produktų asortimentą jų sistemos parduotuvèse.

Interviu metu buvo nustatyta, kad tirtų prekybos centrų vadybininkai, rinkdamiesi produktus savo sistemos parduotuvėms, dažniausia pirmenybę teikia ju kainai, kuri taip pat derinama su būsimomis tų produktų akcijomis ir nuolaidomis, t.y. kokią produkto kainą galima pasiūlyti akcijų laikotarpiu. Taip pat svarbūs kriterijai yra produkto pakuote, kokybè, tiekejjo turimi sertifikatai ir transportavimo sąlygos. Mažiausiai svarbūs produktų atrankos kriterijai, prekybos centrų atstovų nuomone, yra prekès ženklas, ekologiškumo aspektai ir produkto sudètis.

Interviu metu nustatyta, kad tirtų prekybos centrų vadovams ir vadybininkams trūksta informacijos apie Sąžiningos prekybos produktų tiekimo kanalus, kadangi minètų centrų atstovai teigè nežinantys tiesioginių šių produktų tiekimo šaltinių. Dažniausiai Sąžiningos prekybos produkcija tèra papildoma produkto rūšis, 
siūloma kartu su kitais tam tikro tiekèjo kompanijos gaminamais ar tiekiamais importuojamais produktais. Pagrindinę kliūtį, kuri trukdo didinti SP produkcijos asortimentą, prekybos centrų atstovai j̇vardino aukštą kainą, dèl kurios produktai yra mažo apyvartumo - užima prekybos vietą, yra lètai parduodami, o jų pelningumas, palyginti, mažas. Prekybos atstovai tvirtino, kad minètų produktu pirkimas šiuo metu yra tapatus pinigu „išaldymui“ - didelį kiekị užsakyti galima, tačiau jo parduoti greitai nepavyks, nes, komersantų nuomone, niekas Lietuvoje Sąžininga prekyba nesidomi ir tuo labiau vengia pirkti brangiau kainuojančius kasdienio vartojimo produktus.

Apibendrinus interviu rezultatus, galima padaryti išvadą, kad prekybos tinklų vadovybè būtu daugiau linkusi prekiauti Sąžiningos prekybos produktais ne socialinès atsakomybès motyvais, o tik esant galimybei juos parduoti brangiau. Prekybos centrų darbuotojams taip pat kaip ir vartotojams trūksta informacijos apie tai, ką reiškia Sąžiningos prekybos judèjimas, kaip galima skatinti šią socialinę atsakomybę trečiụjų šalių atžvilgiu bei kokie pagrindiniai šios produkcijos tiekejjai. Taigi, ugdytina tiek vartotojų, tiek ir visų prekybos organizacijų vadovų ir atsakingų darbuotojų bendroji socialinè atsakomybe ir ekologinè kultūra.

\section{Sąžiningos prekybos produktų realizavimo plètros galimybiụ Lietuvoje modelis}

Remiantis aukščiau pateikta mokslinès literatūros ir SP produktų pardavimų analize bei autorių atlikta vartotojų ir prekybos centrų atstovų apklausa, buvo parengtas SP produktų realizavimo plettros galimybių
Lietuvoje modelis (žr. 3 pav.). Šio modelio priemoniu igyvendinimas leistų Lietuvos vartotojams geriau įsisąmoninti minètos prekybos koncepcijos esmę, padètų keisti jų elgseną bei ugdyti gyventojų, prekybos centrų vadovų ir vadybininkų socialinị atsakingumą. Pagrindiniai šio modelio subjektai yra:

- visuomeninė Sąžiningos prekybos organizacija - tai piliečių savanoriškas susivienijimas, sudarytas bendriems narių poreikiams ir tikslams tenkinti bei igyvendinti (LR Visuomeninių organizaciju istatymas) - šiuo atveju, tai skatinti SP ir plačiau skleisti informaciją apie ją Lietuvoje;

- vartotojai - augančio socialinio atsakingumo asmenys, sąmoningai įsigyjantys arba ịsigysiantys SP produktus;

- prekybos centrai - ne tik pagrindinè vieta, kurioje galima įsigyti SP produktus, bet taip pat ir socialiai atsakinga šalis, užtikrinanti šių produktų realizavimo plètros igyvendinimą;

- nacionaliné importo organizacija - jos tikslas yra apjungti visus tiekejus ir sudaryti tiesioginius ryšius su trečiųju šalių gamintojais. Ji turetų būti atsakinga už SP produktų tiekimą ir paskirstymą bei bendradarbiavimą, užtikrinant sąžiningą prekybą, tinkamos kainodaros nustatymą ir palaikymą.

Esminis modelio objektas - sveikas ir kokybiškas trečiųjų šalių gyventojų pagamintas ir SP sertifikavimo ženklu pažymètas produktas, kuris ne tik atneša naudą visiems šio modelio subjektams, bet svarbiausia - užtikrina trečiųjų šalių bendruomenių vystymąsi ir padeda joms sąžiningai dalyvauti tarptautiniuose mainuose ir prekyboje.

Modelio igyvendinimas apima 6 etapus, t.y. atsakingos visuomeninès organizacijos kūrimas, vartotojų ir prekybininkų 
socialinio ir ekologinio sąmoningumo ugdymas, SP produktų ir tiekimo kanalų paieška, SP produktų realizavimas ir grį̌ztamasis ryšys, kurių kokybiškas ịgyvendinimas yra būtinas užtikrinant Sąžiningos prekybos produktų realizavimo plètrą. Toliau aptariami kiekvienas iš minetų etapų (žr. 5 pav.).

\section{1 etapas: Visuomeninés organizacijos} steigimas.

Sąžiningos prekybos judejimas prasidejo nuo to, kad pavienès nepelno organizacijos, turejjusios vieną bendrą tikslą - užtikrinti sąžiningą prekybą su trečiosiomis šalimis, - èmèsi to igyvendinimo ir sukūrè platų specializuotų parduotuvèlių tinklą, kuris ilgainiui sąlygojo vieningo SP produktų ženklinimo užtikrinimą, tarptautinių ir nacionalinių asociacijų steigimą ir vieningos SP sistemos sukūrimą. Autorių nuomone, ir Lietuvoje tikslinga įsteigti visuomeninę organizaciją, kuri atstovautu SP judejimo ir produktų viešinimo skatinimą Lietuvoje. Šiuo metu Lietuvą SP produktais neformaliai „aptarnauja“ Suomijos SP organizacijos.

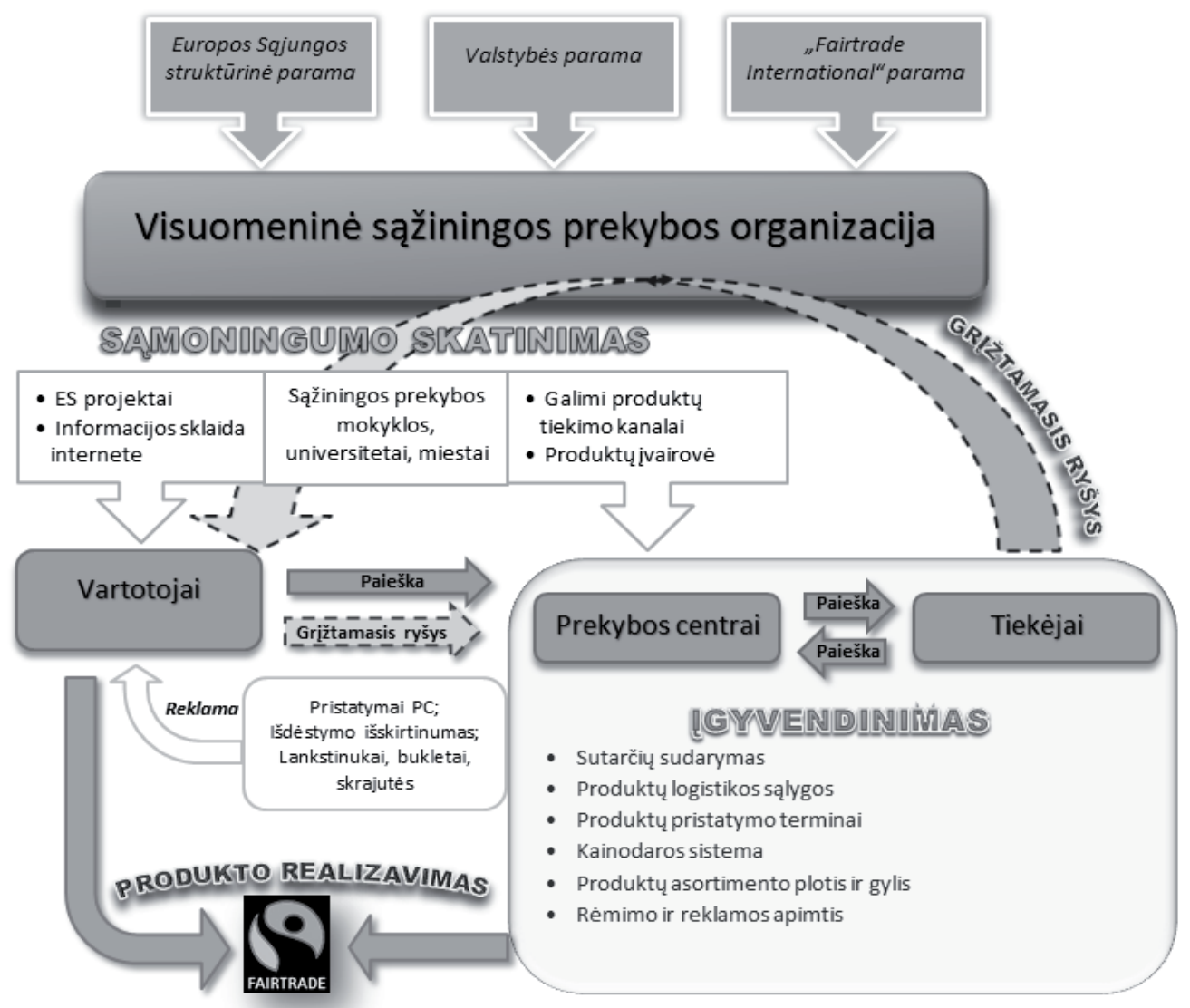

5 pav. Sąžiningos prekybos produktų realizavimo plètros galimybių Lietuvoje modelis. 
2 etapas: Vartotoju ir prekybininky socialinio ir ekologinio samoningumo ugdymas.

Sąmoningumo ugdymas turètų apimti tiek vartotojus, tiek ir (visų pirma!) prekybos organizaciju vadovus ir vadybininkus. Vartotojų sąmoningumo ugdymas gali būti pasiekiamas įvairiais būdais. Kaip rodo užsienio šalių praktika, igyvendinant minètą tikslą, yra panaudojamos tiek valstybès, tiek ir verslo organizacijų ịvairios iniciatyvos bei lešos. Yra taip pat Europos Sajungos remiami projektai. 2013-2015 metais yra vykdomas PRICE projektas (Promoting..., 2013), kurio metu įvairiose šalyse bus rengiami atviri seminarai, siekiant pasidalinti skirtinga šalių praktika, šviesti visuomenę ir kelti susidomejjimą nesąžininga prekyba su trečiosiomis šalimis. Taip pat labai padètų informacijos sklaida internetiniuose puslapiuose bei socialiniuose tinkluose, kuriuose vartotojai praleidžia vis daugiau laiko dalindamiesi naujienomis.

Be to, autorių nuomone, visų pirma yra būtinas prekybos organizacijų vadovų ir aukščiausio lygio vadybininkų švietimas, jų socialinio atsakingumo ugdymas, atskleidžiant Sąžiningos prekybos vertybinius siekinius bei užsienio šalių gerąsias praktikas šioje srityje. Autorių atlikta apklausa atskleide, kad Lietuvos vartotojai ne tik norètų įsigyti šiuos produktus, bet taip pat ir būtų linkę už juos mokèti brangiau. Todèl tikètina, kad šis faktas galètų tapti vienu iš papildomų motyvų prekybos centrų vadovams plèsti Sąžiningos prekybos prekių asortimentą Lietuvos parduotuvèse. Visuomeninès Sąžiningos prekybos organizacijos vienu iš uždavinių galètų būti prekybos organizacijų vadovų ir vadybininkų supažindinimas su galimais tiekimo kanalais ir SP produktų įvairove bei jų kokybès ypatumais.

\section{3 etapas: SP produktu ir tiekimo ka- nalų paieška.}

Visuomeninei organizacijai ìvykdžius labai svarbų antrajj etapą, be kurio negalètų būti užtikrinama veiksminga Sąžiningos prekybos produktų realizavimo plètra, vykdytinas trečiasis etapas - produkto, tiekimo kanalų bei gamintojų paieška. Sužadinus vartotojų susidomejjimą SP produktais, natūraliai seka šių produktų paieška pagrindinèse šių prekių ísigijimo vietose. Po atliktos internetinès vartotojų apklausos paaiškejjo, kad vartotojai šiuos produktus norètu j̇sigyti didžiuosiuose prekybos centruose, kur dažniausiai ir apsiperka, o specializuotų parduotuvèlių steigimas, kaip teigiama, neatneštú papildomos naudos skatinant šių produktų pardavimus Lietuvoje.

Prekybos centrų vadovai, paveikti švietėjiškos SA visuomeninès organizacijos veiklos ir dèl augančios SP prekių paklausos, tikètina ims ieškoti tiekèjų, kurie sugebètų aprūpinti prekybos tinklus SP produktais. Šioje vietoje yra trys galimi pasirinkimai:

1. Savarankiškai importuoti prekes iš trečiųjų šalių gamintojų organizacijų autorių nuomone, tai būtų pati efektyviausia SP, nes tiekimo grandinèje būtų tik gamintojas (atstovaujamas per kooperatyvus) ir vienas pardavejas. Tokiu atveju šie produktai turètų būti pigesni, nes nèra ilgos tiekèjų grandinès antkainių (pelno) sistemos, kuri daro šiuos produktus mažiau komerciškai patraukliais.

2. Ieškoti galimų SP tiekejjų, jau patyrusių šioje srityje, kurie galètų tarpininkauti tarp prekybos centrų ir gamintojų, nustatant prekybos sąlygas, logistikos, pristatymo terminus ir kt.

3. Nacionalinès importo organizacijos, apjungiančios tiekejjus ir gamintojus, kūrimas - tai taip pat efektyvus būdas Sąžiningai prekybai plètoti. Šiuo atveju 
prekybos centrams nereikètų investuoti savo lěšu i gamintojų paiešką, viskuo pasirūpintų importuojančioji organizacija, kuri ir būtų vienintelè tarpinè grandis tarp trečiųjų šalių ir Lietuvos Sąžiningos prekybos produktų rinkos.

Savo ruoštu tiekejai ir gamintojai turètų ieškoti galimų SP produkcijos pardavimo vietų. Egzistuojant prekybos centrų vadovybès suinteresuotumui prekiauti šiais produktais, tarpusavio verslo ryšiai galètų būti sudaromi lengviau ir paprasčiau, nes nuo tiekèjų pečių būtų nuimamas sunkus darbas - itikinti prekybos centrus, kad SP atneša ne tik socialinę, bet ir ekonominę naudą.

\section{4 etapas: Igyvendinimas.}

Tai vienas iš svarbiausių etapų, kurio metu prekybos centrai su tiekejjais (tiek su gamintojais, tiek su nacionaline importo organizacija) galètų sudaryti partnerystès sutartis ir siektų tarpusavio santykius organizuoti taip, kad vartotojams būtų pasiūlomas kuo kokybiškesnis, lengviau prieinamas ir akivaizdžiau pateikiamas SP sertifikuotas produktas. Šiam tikslui pasiekti būtina susitarti dèl produktų logistikos, pristatymo terminų, kainodaros sistemos, produktų asortimento pločio ir gylio, rèmimo ir reklamos apimties bei kita.

Svarbu, kad vartotojus, kurių nepasiekè visuomeninès organizacijos skleidžiama informacija, pasiektų SP produktų reklama prekybos centruose - skrajutès, lipdukai, bukletai ir kita informacinè medžiaga, skelbianti apie šio judejjimo prasmę ir naudą.

Nemažiau reikšmingas dalykas yra pačių produktų pateikimas ir išdèstymas prekybos centruose. Apklausa atskleide, kad viena iš esminių problemų yra ta, kad vartotojai nežino, kur galima būtų ịsigyti Sąžiningos prekybos produktus. Šios problemos sprendimu turi rūpintis ne tik visuomeninė organizacija, skleisdama aktualią informaciją, bet taip pat ir prekybos centrai, kuriuose Sąžiningos prekybos produkcija turètų būti atskirta nuo kitú prekių, lengvai pastebima ir patraukianti dèmesį. Papildomai būtų galima rengti prezentacijas ir degustacijas pačiuose prekybos centruose, kurių metu būtų atskleidžiami SP produktų kokybès ypatumai, pagrindinès šio judejjimo idejjos, kartu su galimybe vartotojams betarpiškai išbandyti šiuos produktus.

\section{5 etapas: SP produktų realizavimas.}

Kai vartotojai yra supažindinti su Sąžiningos prekybos idejomis, prekybos centrai ir tiekejai sudarę sutartis, numatę pagrindinius produkcijos tiekimo aspektus, tuomet sèkmingiau gali klostytis ir patys SP produktų pardavimai. Iš to naudą gauna visi šios sistemos dalyviai: vartotojams teikiama sveika ir kokybiška produkcija, prekybos centrams tai yra dar viena socialinès atsakomybès priemonè ir savireklama, o tiekejjai, užtikrindami sąžiningus mainus, padeda trečiųų šalių bendruomenių vystymuisi.

Plečiantis SP produktų apyvartai Lietuvoje, galima būtų igyvendinti ir kitus projektus bei skleisti idejas, prekiaujant šiais produktais ne tik prekybos centruose. Pasaulyje šiuo metu taip pat veikia Sąžiningos prekybos mokyklos, kolegijos ir universitetai, kuriuose yra skelbiamos Sąžiningos prekybos idejos, jos taip pat viešinamos visiems aplinkiniams bei bendruomenėms. Be to, užsienio šalyse yra net ir Sąžiningos prekybos miestų, kuriuose plačiai galima įsigyti šiuos produktus, organizuojamos ịvairios mugès bei bendros priemonès ir veiklos, padedančios trečiosioms šalims.

\section{6 etapas: Grižtamasis ryšys.}

Tai paskutinysis, bet ne mažiau svarbus etapas, užtikrinant SP produktų 
realizavimo sèkmingą plètrą. Modelyje atspindèti trys grižžtamojo ryšio aspektai. Visų pirma, būtina sukurti veiksmingo grį̌żamojo ryšio „vartotojas - prekybos centras" galimybes. Tai reikalinga, kad būtų nuolatos vertinama SP produktų kokybe ir asortimentas, taip pat vartotojų preferencijos šių produktų asortimento atžvilgiu - kokių produktų trūksta, kokių jie pageidautų, kurie yra priimtiniausi ir pan.

Taip pat turi būti užtikrinamas grị̌žtamasis ryšys visuomeninei Sąžiningos prekybos organizacijai, kuri matuotų, sektų ir vertintų SP produktų pardavimus, spręstų, kaip galima būtų padidinti šių produktų pardavimus, sužadinti didesni vartotojų susidomèjimą ir ísitraukimą ị socialiai atsakingą veiklą - Sąžiningos prekybos mokyklų, universitetų ir miestų kūrimą.

Trečiasis grịžtamojo ryšio aspektas vartotojai turètų būti sistemingai informuojami: kokią konkrečią naudą iš jų pasirinkimo pirkti Sąžiningos prekybos produktus gavo trečiųjų šalių gyventojai. Tą turètų daryti SP prekių tiekejjai ir Nacionalinè importo organizacija. Jie perduotų konkrečią informaciją visuomeninèms organizacijoms, o pastarosios per ịvairius informacijos šaltinius toliau skleistų ją vartotojams. Autorių nuomone, užtikrinus grị̌žtamąji ryši vartotojams, galima būtų toliau skatinti Sąžiningos prekybos produktų pardavimus ir ugdyti gyventojų socialinị atsakingumą.

\section{Išvados}

Sąžiningos prekybos (SP), kaip su darniuoju vystymųsi susietos socialinès atsakomybès reiškinio ir naujos tarptautinès ekonominès veiklos fenomeno, užuomazgos atsirado daugiau kaip prieš 60 metų. ES šiuo metu inicijuoja keletą kompleksinių tyrimų, nukreiptų i Sąžiningos prekybos idejos sklaidą ir populiarinimą, jos koncepcijos konsolidavimą, vartotojų ir prekybos organizacijų darbuotojų socialinio atsakingumo ugdymą, informacijos srauto didinimą ir šių produktų realizavimo Europoje plètrą. Išanalizavus SP koncepcijos sąvokas ir sampratas, galima daryti apibendrinimą, kad dažniausiai ši tarptautinè socialinès atsakomybės priemonè išreiškiama per sąžiningos ir tradicinès prekybos skirtingumus ir geresnių prekybos bei darbo sąlygų sudarymą trečiųjų šalių gamintojams ir darbuotojams.

Atlikus Lietuvos vartotojų apklausą buvo nustatyta, kad beveik pusè respondentų visiškai nežino, kas tai yra Sąžininga prekyba. Tačiau sužinoję apie SP socialinius tikslus ir teikiamą naudą trečiųju šalių gyventojams, didžioji dalis (95 \%) apklaustų vartotojų būtų linkę įsigyti šiuos produktus, o beveik trečdalis (27\%) - juos pirktų nuolatos. Prekybos tinklų vadovai kol kas nèra linkę plèsti SP produktų realizavimo ir asortimento dèl dviejų priežasčių. Pirma, kol kas nedidelè šių gaminių paklausa, sąlygojama menko vartotoju informuotumo tiek SP siekių, tiek ir šių produktų kokybės ypatumų srityse. Antra, didžiosios dalies prekybos organizaciju vadovų ir vadybininkų vertybinių orientacijų, susietų su socialine atsakomybe ir ekologija, branda yra menka.

Atlikus respondentų pakartotinių vertinimų dispersinę analizę buvo nustatyta, kad svarbiausias veiksnys, itakojantis Sąžiningos prekybos plètrą, šių produktų pardavimus ir vartojimą, yra platesnè informacijos sklaida apie SP esmę ir siekius, šių produktų kokybès ypatumus ir jų pardavimo vietas. Taip pat nustatyta, kad vartotojams yra svarbesnis šių produktų pasirinkimo didinimas prekybos centruose, palyginus su specializuotų skyrelių ar 
atskirų parduotuvių tinklų steigimu.

Autorių teikiamas modelis atskleidžia Sąžiningos prekybos plètros Lietuvoje galimybes. Siekiant užtikrinti SP produktų realizavimo plètrą, tikslinga pradèti nuo visuomeninès SP organizacijos steigimo, kuri atlikdama tam tikrus tyrimus, skleisdama ir viešindama informaciją apie ši judejjimą, skatintų tiek vartotojus pirkti SP prekes, tiek ir motyvuotų prekybos centrų vadovus bei vadybininkus ieškoti kelių ir būdų formuoti parduotuvèse didesnę šių produktų ịvairovę. Kita vertus, tiekejjams, gamintojams arba juos vienijančiai nacionalinei importo organizacijai ir prekybos centrams nustačius partnerystès ryšius bei sukūrus tinkamus produktų tiekimo kanalus, vartotojams būtų pasiūlytas ir platesnis bei išsamesnis SP produktų asortimentas. Ypatingą reikšmę SP plètrai turi vartotojų ir prekybos darbuotojų socialinio atsakingumo ir ekologinès kultūros ugdymas.

\section{Literatūra}

1. Blowfield, M., Dolan, C. (2010). Outsourcing governance: Fairtrade's message for C21global governance. Corporate Governance, Vol. 10, No. 4, pp. 484-499.

2. Comfort, D., Hillier, D., Jones, P. (2003). Retailing fair trade food products in the UK. British Food Journal, Vol. 105, No. 11, pp. 800-810. doi: 10.1108/00070700310511591.

3. Eisenberg, J. (2005). Free Trade Versus Fair Trade.Prieiga per internetą: <http://www. globalenvision.org/library/15/834>, [Žiūrèta $20121025]$.

4. ES struktūrinès paramos veiksmų programa 2014-2020 m. Prieiga per internetą: <http://www. esparama.lt/2014-2020-laikotarpis/diskusijos>, [Žiūrèta 201312 17].

5. Europos Komisija, EuropeAid (2011). Vystomasis švietimas Europos Sąungoje. Gairès pareiškejjams. Prieiga per internetą: <https://webgate. ec.europa.eu/europeaid/online-services/index.c $\mathrm{fm}$ ?ADSSChck $=1317457494764 \&$ do $=$ publi.det PUB\&searchtype $=$ QS\&orderby=upd\&orderbya $\mathrm{d}=$ Desc\&nbPubliList $=15$ \&page $=1$ \&aoref $=1311$ 41>, [Žiūrèta 201312 17].

6. Fairtrade Foundation. Fairtrade Certification and the FAIRTRADE Mark. Prieiga per internetą: <http://www.fairtrade.org.uk/ what_is_fairtrade/fairtrade_certification_and_ the_fairtrade_mark/default.aspx $>, \quad$ [Žiūrèta $20121201]$.

7. Fairtrade International (2011). „For producers with producers“. Annual Report. Prieiga per internetą: <http://www.fairtrade.net/fileadmin/ user_upload/content/2009/resources/201112_AnnualReport_web_version_small_
FairtradeInternational.pdf $>$,

[Žiūrèta 201212 26].

8. Fairtrade International, (2013). „Unlocking the power".Annual Report. Prieiga per internetą: <http://www.fairtrade.net/fileadmin/user_ upload/content/2009/resources/2012-13_ AnnualReport_FairtradeIntl_web.pdf>, [Žiūrèta 20140105 ].

9. Gibbon, J., Sliwa, M. (2012). Critical perspectives on Fair Trade: an introduction. Critical perspectives on international business, Vol. 8, No. 4, pp. 272-276. doi: $10.1108 / 17422041211274219$.

10. Hockerts, K. (2005). The Fair Trade Story. Oikos Sustainability Case Writing Competition. Prieiga per internetą: <http://www.fairtrade. at/fileadmin/user_upload/PDFs/Fuer_Studierende/oikos_winner2_2005.pdf>, [Žiūrèta $20121201]$.

11. Jaffee, D. (2010). Fair Trade Standards, Corporate Participation, and Social Movement Responses in the United States. Journal of Business Ethics.Vol. 92, pp.267-285. doi: 10.1007/ s10551-010-0583-1.

12. Kocken M. (2006). Sixty Years of Fair Trade. A brief history of the Fair Trade movement. IFAT. Prieiga per internetą: <http://www.europeanfair-trade-association.org/efta/Doc/History. pdf>, [Žiūrèta 20121124 ].

13. Lietuvos Respublikos Visuomeninių organizacijų istatymas (Nr. VIII-785, 98.06.11, Žin., 1998, Nr.59-1653 (98.07.01)). Prieiga per internetą: <http://www3.lrs.lt/pls/inter3/oldsearch.preps 2 ? Condition $1=59154 \&$ Condition $2=>$, [Žiūrèta $20131102]$. 
14. Loureiroa, M. L., Lotade, J. (2005). Do fair trade and eco-labels in coffee wake up the consumer conscience?Ecological Economics, No. 53, pp. 129- 138.

15. Mathieu S., d'Astous A. (2008). Inciting consumers to buy fairly-traded products: a field experiment. Journal of Consumer Marketing, Vol. 25, No. 3, pp. 149-157. doi: $10.1108 / 07363760810870644$.

16. Nicholls, A., Opal, C. (2005). Fair Trade: Market-driven ethical consumption.London: Sage Publications.

17. Nicholls, A.J. (2002). Strategic options in fair trade retailing. International Journal of Retail \& Distribution Management, Vol. 30, No. 1, pp. 6-17. doi: 10.1108/09590550210415220.

18. Promoting Responsible Investments and Commerce in Europe (2013). Prieiga per internetą: <http://thepriceproject.org/>, [Žiūrèta $20131101]$.

19. Redfern, A., Snedker, P. (2002). Creating market opportunities for small enterprises: experiences of the fair trade movement. International Labour Office. Seed working paper, No. 30, pp.20-32.
20. Ruževičius, J. (2011). Analysis of the international system of social responsibility tools. Issues of Business and Law, 2011, Vol. 3, pp. 44-61. doi: 10.2478/v10088-011-0005-5.

21. Ruževičius, J. (2012a). Étude des novations du système européen de certification de la qualité. International Business: Innovations, Psychology, Economics, 2012, Vol. 3, No. 1 (4), pp. 7-39.

22. Ruževičius, J. (2012b). Management de la qualité. Notion globale et recherche en la matière. Vilnius: Maison déditions Akademinè leidyba.

23. Smith, A. (2011). Fair and Ethical Trade: An Explanation. WIEGO. Prieiga per internetą: $<$ http://wiego.org/sites/wiego.org/files/ resources/files/Global-Trade-What-Fair-andEthical-Trade.pdf>, [Žiūrèta 201211 25].

24. Strong, C. (1997). The problems of translating fair trade principles into consumer purchase behaviour. Marketing Intelligence and Planning, No. 15/1, pp. 32-37. doi: $10.1108 / 02634509710155642$.

25. Wynne, S. (2008). The Challenges of Marketing Fair Trade. Master Thesis. Prieiga per internetą: $<$ http://sandywynne.com/thesis.pdf $>$, [Žiūrèta 201309 10].

Straipsnis ịteiktas: 20140122

Parengtas publikuoti: 20140303

\section{Alina KAIRAITYTÉ, Juozas RUŽEVIČIUS OPPORTUNITIES OF FAIRTRADE DEVELOPMENT IN LITHUANIA}

\section{$\mathrm{S}$ u $\mathrm{m} \mathrm{m}$ a r y}

The main purpose of this article is to propose the model of Fairtrade products' development in Lithuania, after analyzing the Fairtrade system, as a social responsibility tool. The paper consists of the three main parts: the analysis of literature, research with its results and a developed model with conclusions and recommendations.

There were varieties of methods applied: literature and document analysis, the comparison method, the survey method, the structured questionnaire interview method and synthesis methods. Based on scientific literature, the Fairtrade concept analysis, and a summary of the main problems in the distribution of Fairtrade products, the model was created that should help to spread Fairtrade ideas in Lithuania, and in turn, should produce quality for us, improve the third-world's life and secure a bright future.
The literature analysis reviews the Fairtrade concept and its variety of definitions. The most widely used definition is given by Fairtrade International, which states that Fairtrade is a trading partnership, based on a dialogue, transparency and respect that seeks greater equity in international trade. It contributes to sustainable development by offering better trading conditions to, and securing the rights of marginalized producers and workers especially in the South. The article also presents the history of the movement evolution when the first real manifestations appeared in the mid-twentieth century, and the overall Fairtrade system, including associated organizations, standards and marking, which all have been still developed.

Throughout the world, Fairtrade marked goods are widely available in supermarkets, world shops 
and it is reported that more than half of the respondents are aware about Fairtrade and buy these products. However, in Lithuania there are no research articles on these topics, and also information in media about the Fairtrade movement and its meaning is missing. And while people can buy such goods in Lithuania, human unconsciousness and brand anonymity discourage sales of these products. According to the Fairtrade International statistics, the turnover of fairtrade products in 2011 has increased in $12 \%$, however in Lithuania it decreased significantly by $17 \%$. The authors present 3 scientific references which explain the main reasons why people do not purchase Fairtrade products and what are the key factors to improve the turnover of Fairtrade products.

The research was divided into two analyses: internet survey of consumers of 20-60 years- there were 406 respondents questioned that satisfied with the research to understand the demand of Fairtrade products, and also four representatives of supermarkets were examined to discuss whether super- markets would be interested to improve the Fairtrade products' turnover. The research data were processed by the statistical analysis program SPSS. Descriptive statistics methods were used for data analysis (means calculations, correlation analysis, chi-square tests, etc.).

To conclude, the research showed that a vast majority of respondents did not know the meaning of Fairtrade. However, they were willing to buy Fairtrade products even for a higher price after they had been explained of it. The representatives of supermarkets stated that they would propose more of Fairtrade products if consumers show the demand. Therefore, the author suggested a model which should help to increase the Fairtrade products' turnover - there must be a non-profit-making organization established in Lithuania which should spread the information about Fairtrade objectives, so that people would know and understand the meaning of it. There also must be a feedback system created so that consumers could feel the satisfaction and see the changes their purchases make in the third world countries. 